\title{
IKONOMIKA
}

Jurnal Ekonomi dan Bisnis Islam (Journal of Islamic Economics and Business)

Volume I, Nomor 2, Oktober 2016

ISSN: 2527-3434 (PRINT) - ISSN: 2527-5I43 (ONLINE)

Page: I05-II7

\section{INFLUENCE OF CONSUMERS KNOWLEDGE TO SHADAQAH PAYING DECISION AT BAITUL MAAL UNISBA}

\author{
Ratih Tresnati, Lufthia Sevriana\&Eneng Nur Hasanah \\ UNISBA,Bandung,Indonesia \\ ratihtresnati27@,gmail.com, lufthia.sevriana@,unisba.ac.ud, \&enengnurhasanah@,gmail.com
}

\begin{abstract}
Shadaqah has a very important role to every human when we leave this world, therefore moslem community build a foundation to take care of their shadaqah from Muzaki. Unisba as an Islamic University, also have organization to collect, manage, and allocate funding from shadaqah, named Baitul Maal of Unisba. There are 419 lecturers and employees in Unisba but there are only 27\% from them who decide to become muzzaki at Baitul Maal of Unisba. On average, the Collected Fund at Baitul Maal of Unisba per month is only as many as Rp 3.000.000,-Researchers assumed that it caused by lack of consumers knowledge about Baitul Maal of Unisba programs. Consumers knowledge consists of attributes, benefit, and satisfaction to the products or services. A total of 30 questionnaires from offline surveys has been analysed using "several statistical analysis", including multiple regression. Result of this research shows us that satisfaction to the products or services is the most dominant variable that influence lecturers and employees to become muzzzaki at Baitul Maal of Unisba.
\end{abstract}

Keywords:Consumers Knowledge, Paying Decision, Muzzaki, Baitul Maal of Unisba

\begin{abstract}
Abstrak- Shadaqahmemilikiperanan yang sangat penting bagi setiap manusia ketika akan meninggalkan dunia yang fana, itulah sebabnya komunitas muslim membangun lembaga untuk mengelola shadaqah nya dari Muzzaki. Unisba sebagai Universitas yang islami, juga memiliki organisasi untuk mengumpulkan, mengelola, dan mengalokasikan pendanaan dari shadaqah, yang bernama Baitul Maal Unisba. Terdapat 4I9 Dosen dan staff karyawan du Unisba, namun yang menjadi muzakike Baitul Maal Unisba hanya 27\% dari jumlah tersebut. Begitu juga bila dilihat dari jumlah dana shadaqah dan infaq yang masuk kekas Baitul maal per bulannya kurang lebih hanya Rp. 3.000.300. Hal tersebut diduga kurangnya pengetahuan konsumen
\end{abstract}




\section{Influence Of Consumers Knowledge To Shadaqah paying Decision \\ At Baitul Maal UNISBA}

(Ratih Tresnati, Lufthia Sevriana \& Eneng Nur Hasanah)

tentang program-program Baitul- maal Unisba. Pengetahuan konsumen terdiri dari pengetahuan atas atribut, manfaat, dan kepuasan terhadap suatu produk atau jasa. Sebanyak 30 kuesionerdari hasil survey offline dianalisis menggunakan "beberapa analisis statistik", termasuk regresi berganda. Hasil dari penelitian ini menunjukkan variabel kepuasan terhadap produk baitul maal yang paling mempengaruhi keputusan dosen dan karyawan unisba untuk menjadimuzaki di baitulmaal unisba.

Kata Kunci: Consumers Knowledge, Paying Decision, Muzzaki, Baitul Maal Unisba

\section{INTRODUCTION}

The decision making to be a Muzakki to paying the zakah has been the crucial issue in Bandung Isla University. Many of faculty member denial to be of Muzakki in Unisba although they understand the compulsory of zakah as mentioned in Islam's pillar. This phenomenon showed by the number of muzakki and the number of zakah compares to the Unisba faculty members.

This paper to be urgent research because Unisba as one of the Islam University in Bandung with Islam culture should be holding zakah as one of the Islam compulsory. This study also should be a good recommendation to BaitulmaalUnisba to promote their muzakki's program.

The research about the decision making to be a Muzakki to paying a zakah has conducted by (Huda et.al,
20I2) which analysis the muza using The Planned Behavior of (Ajzen, 1988). They found that the muzakki's intention variable influenced by attitudes and control behavior, but the subjective norm do not. Otherwise, (Heikal et al., 20I4) found that the subjective norms, perceived behavioral control and past behavior have a significant effect, they also found that past behavior having dominant effect and attitude has the least impact on the intention to paying zakah.

The problem investigated in this study how BaitulmaalUnisba socialize zakah to the faculty member, how the faculty members know zakah in BaitulmaalUnisba, how is decision making of the faculty member to be a muzakki, and the influenced of consumers knowledge to be a muzakki in BaitulmaalUnisba. 
Zakah as one of the Islam's pillars which mention on some verse in Al Quran. It is one of the responsibility for the Muslim to helping each other. According to the Al Quran (At Taubah:60), the categories of zakah consists of: beggar, poor, zakah collectors, Muallaf (a Muslim who recently converted into Islam), emancipated the slave, debtors, fisabilillah (people who fight in Allah), and wayfarers.

(Samad and Glenn, 2010) compare the zakah according to the three major religions: Judaism, Christianity, and Islam. On Judaism and Christianity, zakah was purely voluntary as a measure to devote and support the society. In Islam, zakah mentioned to be more specified as mention on Al Quran.

In many literature, there are many definitions of zakah. According to Al Quran (At Taubah: 34), zakah called by infaq, essentially zakah is the wealth submission for the goodness because of God commands. Then, zakah called by shadaqah (At Taubah:60\& I03), because one of the zakah function is to tawarruh (closer) to the God. The last, zakah called as haq because of zakah is the compulsory from God for people who deserve it.

Otherwise, (Askari and Taghavi, 2005) define zakah as the charity tax which calculated according to the level of the net worth, it is earnings from the people who can earn more than they can pay.

Different with infaq and shadaqah, zakah is the compulsory and voluntary social expenditure from the other Muslim to help each other, but infaq and shadaqah are donates beyond zakah requirements.

One of the influenced factors of decision purchasing is consumer knowledge. Consumer knowledge is all information regarding to many of product and services, and other knowledge about their function as a consumer.

In general, (Gebert et al., 2003) define customer knowledge is knowledge about, from, and for customers. (Yeung et al., 2008) define that customer preference based on their customer knowledge about the term of products. Then, (Engel, et.al, 1998:337) and(Mowen and Minor, 1998:106) define the customer 
knowledge as the information and experience which relevant with the consumers.

(Garcia-Murillo and Annabi, 2002) divided customer knowledge into two different aspects, which consists of: the knowledge about customer's matter that related to the product or services which they wants, and company action to encourage customer in making a purchase decision.

According to the classification, (Rowley, 2002) divided the consumer knowledge into 3 categories, which consists of: consumers knowledge possessed, segmentation and potential customers, and individual customers.

Otherwise, (Engel et.al, I994:316) divided the consumer knowledge into three kinds of knowledge, which consists of Product Knowledg, Price Knowledge and Purchasing Knowledge.

For a company, understanding the consumer behavior and its influenced factors will show how the customer buying a product. (Kotler and Keller, 20I2:206) define that personal decision making is a step from behavior process of customer buying. It will influenced by psychological factor to understand the customer behavior. (Kotler andAmstrong, 200I:224) and (Lovelock and Wright, 2002:88) defined that decision making proses influenced by three steps, consists of: pre-purchase, purchase, and post purchase activity. Then, (Uotila, 2010) defined that customer knowledge used in the customer decision making and it should be an obstacle in the product utilization.

Decision making is one of the marketing tools to know the customer preferences. (Prue et al., 2015) using leveraging personality models to define the personal factor in the marketing highlights. They use Persuasive Appeal Support Tool (PAST) to understand the market segment's mental state and 
underlying motivations. ( $\mathrm{Lu}$ et al., perceived behavior have significants 2016) review the Multilevel Decision- influenced on muzakki's intention. Making into three main categories: Bi- Otherwise,(Heikal et al., 20I4) found level decision-making (including that the past behavior has dominant multi-objective and multi follower impact on muzakki intention to situations). Tri-level decision-making, and Fuzzy multilevel decision-making. paying zakah.

According to the zakah office

On the decision making management, (Syafei, 20I5) determine framework, (You, et al., 20I4) use RFM (Recency, Frequency and Monetary), CHAID decision trees, and Pareto values to present the precision marking using decision marketing framework by data-mining techniques. This technique used to categorized the potential customer characteristic.

Some related previous research defined the muzakki intention to paying by using the Planned Behavior. (Huda et al., 20I2) used the Planned Behavior Theory to determine the effect some attribute controls to be a muzakki's intention to pay zakah.

This paper showed that the public trust degree on zakah management (the Office of Religious Affairs-KUA), the result show that the public trust is very high, which means that public trust affect to the zakat management quality

\section{METHOD}

Method that we use in this research is qualitative descriptive methods to deeply describe how is the effort of Baitul Maal Unisba to add consumer knowledge to make lecturers and employees motivated to pay shadaqah to Baitul Maal of Unisba.

In order to expose an implementation consumers knowledge of the lecturers and employees Unisba attitudes, subjective norms and 
about Baitul maal of Unisba, the reserach population consists of:

I) The service provider of baitul maal Unisba (back office staff)

2) Lecturers and Employees as muzzaki to know their perception about managerial of baitul maal unisba

The sample that being taken is Permanent Lecturers and Employees of Unisba randomly with simple random sampling technic.

Independent Variable of this reserach is consumers knowledge which consists of all information from consumers point of view about products and services of Baitul maal unisba, with indicators as shown below:

(I) Knowledge about attributes of baitul maal unisba: recognizing the existence of Baitul Maal, knowing the information of Baitul Maal Unisba, knowing the goals of Baitul Maal Unisba.

(2) Knowledge about benefit of Baitul Maal Unisba: knowing the benefit of Baitul Maal Unisba to lecturers and employees of Unisba, knowing the benefit of Baitul Maal Unisba to the fund user.

(3) Knowledge about the value or satisafction that has been given by Baitul Maal Unisba to the lecturers an

employees of Unisba: knowing that paying shadaqah/infaq will purify the whealth, knowing that decision to paying shadaqah in Baitul Maal will get a replyas a pahala from Allah Swt.

Dependent Variable of this research is "decision of lecturers and employees unisba in paying shadaqah/infaq to baitul maal of unisba: I) decision to paying shadaqah/infaq; 2) decision to paying shadaqah/infaq in Baitul Maal Unisba; 3) decision of the amount that will be given as shadaqah or infaq; 4) decision about the exact time to paying shadaqah/infaq to Baitul Maal Unisba. 
Table I

Variable Operasionalisation

\begin{tabular}{|c|c|c|c|}
\hline Variables & Dimensions & Indicators & Data scales \\
\hline $\begin{array}{l}\text { Consumer } \\
\text { knowledge (all } \\
\text { information that } \\
\text { belong to } \\
\text { consumer about } \\
\text { several products } \\
\text { and services }\end{array}$ & $\begin{array}{l}\text { I. Knowledge } \\
\text { about } \\
\text { attributes of } \\
\text { baitul maal } \\
\text { unisba }\end{array}$ & $\begin{array}{l}\text { - recognizing the } \\
\text { existence of Baitul } \\
\text { Maal } \\
\text { - knowing what Baitul } \\
\text { Maal Unisba is } \\
\text { - knowing the goals of } \\
\text { Baitul Maal Unisba. } \\
\text { - knowing how is Baitul } \\
\text { Maal Unisba being } \\
\text { managed } \\
\text { - knowing } \\
\text { information of Baitul } \\
\text { Maal Unisba } \\
\text { - knowing how baitul } \\
\text { maal unisba report its } \\
\text { responsibility of the } \\
\text { shadaqah/infaq that } \\
\text { has been paid by the } \\
\text { lecturers } \\
\text { employees }\end{array}$ & $\begin{array}{l}\text { - Ordinal } \\
\text { - Ordinal } \\
\text { - Ordinal } \\
\text { - Ordinal }\end{array}$ \\
\hline & 2. Knowledge & - knowing the benefit of & - Ordinal \\
\hline
\end{tabular}


(Ratih Tresnati, Lufthia Sevriana \& Eneng Nur Hasanah)

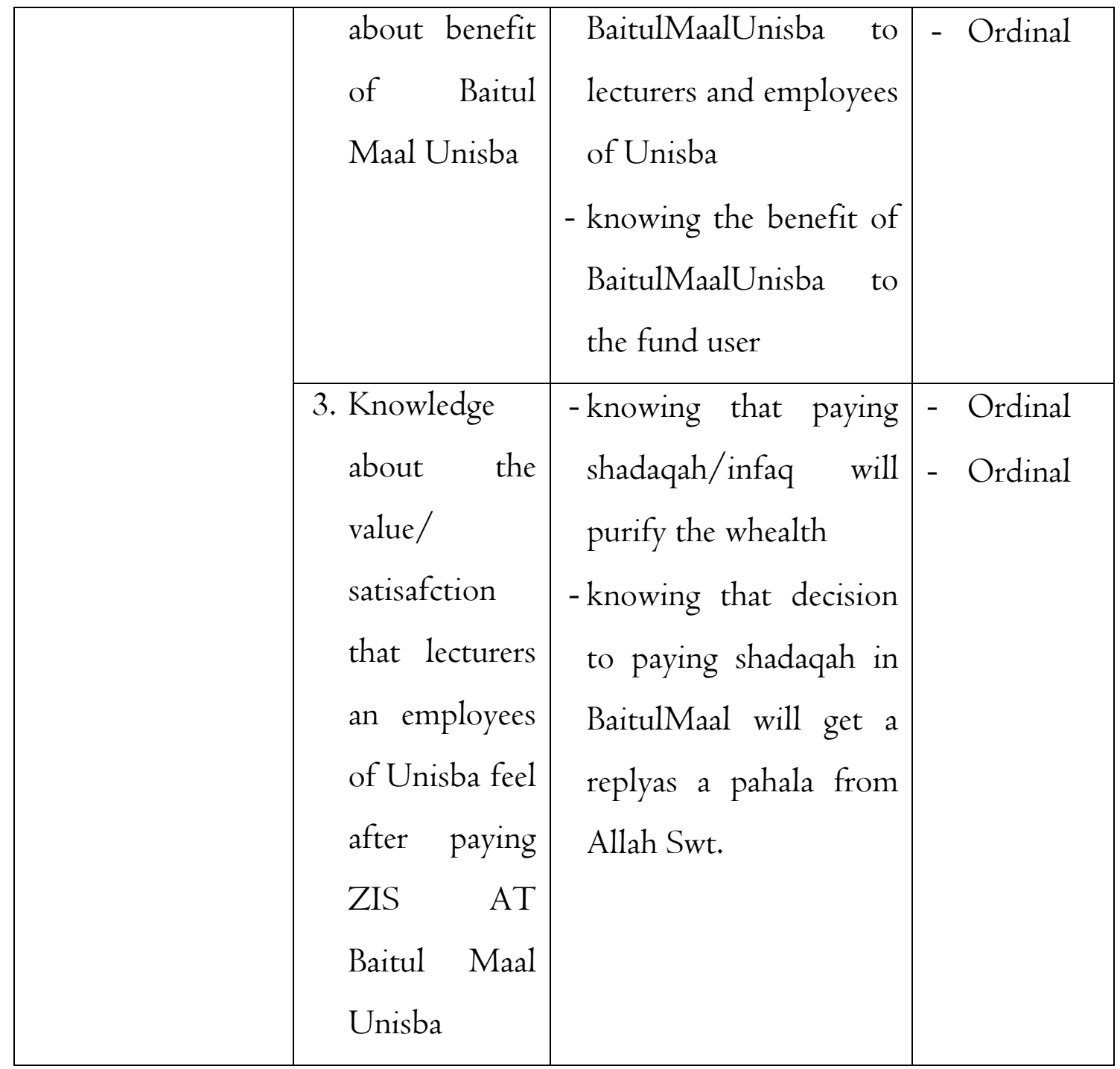


Table 2

Variable Operasionalisation

\begin{tabular}{|c|l|l|}
\hline Variables & \multicolumn{1}{|c|}{ Indicators } & Data scales \\
\hline & $\begin{array}{l}\text { - decision to paying shadaqah/infaq } \\
\text { - decision to paying shadaqah/infaq } \\
\text { Decision to paying }\end{array}$ & - Ordinal \\
shadaqah/infaq to & $-\begin{array}{l}\text { decision of the amount that will } \\
\text { be given as shadaqah or infaq }\end{array}$ & - Ordinal \\
Baitul Maal of Unisba & $\begin{array}{l}\text { decision about the exact time to } \\
\text { paying shadaqah/infaq to Baitul }\end{array}$ & - Ordinal \\
& Maal Unisba. & \\
\hline
\end{tabular}

\section{RESEARCH INSTRUMENT}

I. Questionnaire manual: question or statement points to explain consumers attitude about: description of Baitul Maal Unisba, description of lecturers and employees decision in paying shadaqah/infaq to Baitul Maal Unisba.

2. Interview mannual: question points to the staff of Baitul Maal Unisba to know the managerial of Baitul Maal Unisba also as an effort to make staff of Baitul Maal Unisba to socialize the program of Baitul Maal Unisba.

Consider the result of variable operasionalisation, we got not also independent variable (consumers knowledge) but also dependent variable (decision in paying shadaqah/infaq to Baitul Maal Unisba) is "ordinal" scale. As a result, the reserachers choose skala likert format with five stages, where skala likert usually measuring attitudes, 
opinions, and perceptions from someone

or a group of people about social phenomenon.

A good Research Instrument (Questionnaire Mannual) must completed validity and realiability requirement.

I. Validity

(Rohaety, et.al, 2007:57) states that validity is a measurement that really measure what has to be measured. The higher validity of a test instrument, the instrument really shows what should be measured.

2. Reliability

(Rohaety, et.al, 2007:57) states the meaning of reliability is a reliable level of result measurement. Measurement with high realiability is a measurement that can give a realiable measurement result. To test a realiability of measurement tool or instrument on this research, we use alpha cronbach coefficent.
Reliability coefficient shows a quality of the whole data collection process.

Researchers use multiple regression analysis to know the influence of consumers knowledge to decision in paying shadaqah/infaq at Baitul Maal of Unisba. While in determining whether $\mathrm{Y}$ is $(+)$ or $(-)$, we use correlation coefficient. To know how far variable $\mathrm{X}$ (consumers knowledge) to variable $\mathrm{Y}$ (decision in paying shadaqah/infaq at Baitul Maal of Unisba), we use $\mathrm{R}$ square formulation analysis.

Hypothesis Test

$\mathrm{H}_{0}: \beta=0$, Consumer Knowledge has no influence to decision in paying shadaqah/infaq to Baitul Maal of Unisba.

$\mathrm{H}_{\mathrm{i}}: \beta \neq 0$, Consumer Knowledge has influencing decision in paying shadaqah/infaq to Baitul Maal of Unisba.

Significance Test to thise hypothesis was conducted with t test with 0.05 significance level with $\mathrm{dk}=\mathrm{n}-2$.

\section{RESULT ANDDISCUSSION}

A total of 30 questionnaires were distributed. The respondents consisted of various age groups and level of education. 3.70 percent of the respondents were at tge ages of 25 years and below, $3.70 \%$ between the ages of 26-35 years, $18.52 \%$ between 
the ages of $36-45$, and $74.07 \%$ were at the ages of 45 years and above.

Respondents' level of education was as follolws: II.II\% had a high school education, $18.52 \%$ had a bachelor's degree, II.II\% had a doctoral degree, and 59.25\% had a master degree. $33.33 \%$ of the respondents came from employee of unisba, II.II\% came from the DPK lecturers, and $55.55 \%$ came from the lecturers of unisba.
Regression analysis were used to test the proposed hypotheses. This study has one dependent variable and three

The table above, represens the results of the regression analyses. The coefficient of $\mathrm{R}$ square is 0.503 indicating that all independent variables account for $50.3 \%$ of the

variance in consumers knowledge of decision to pay shadaqah.

Table 4

Correlations

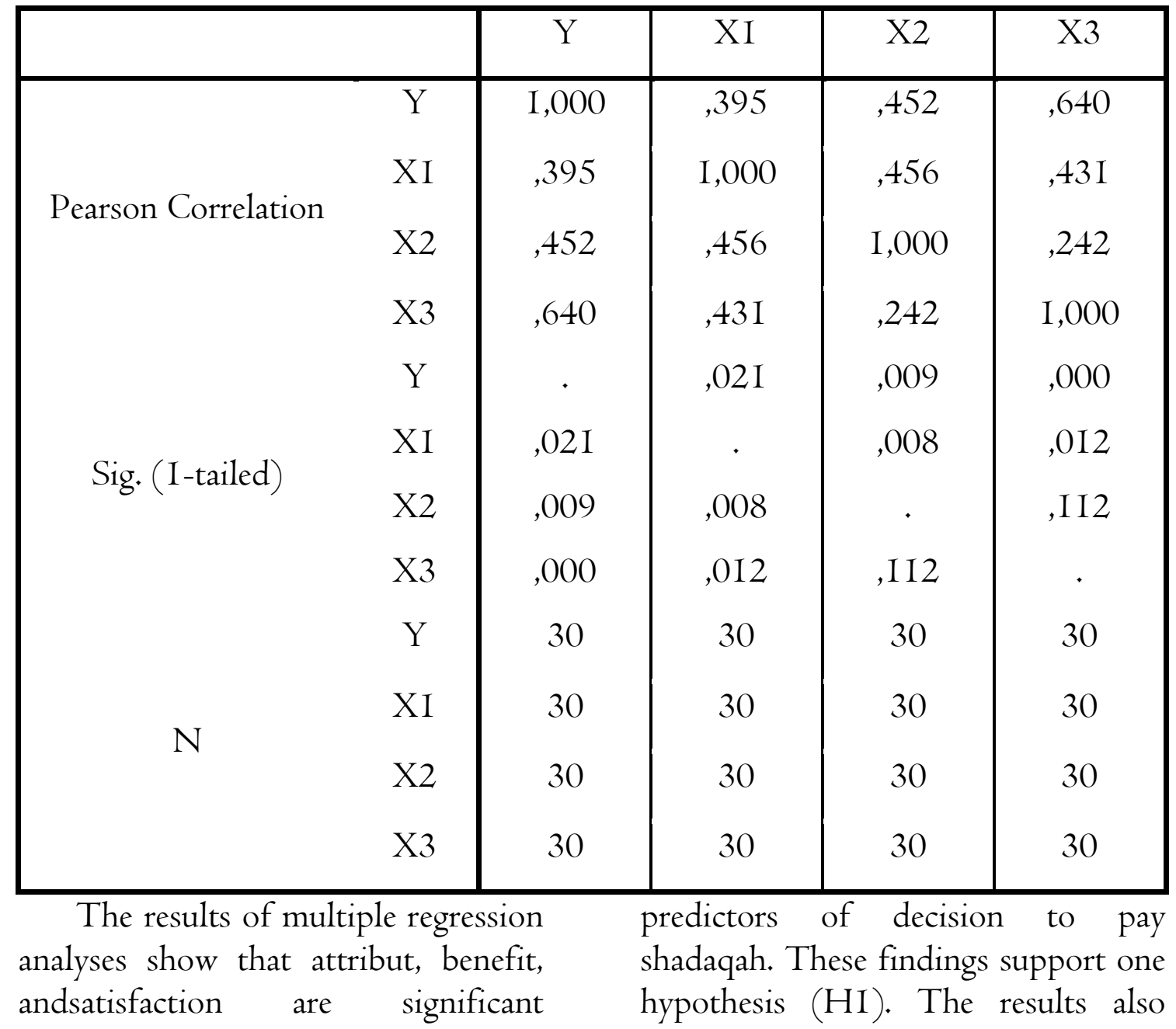


show insufficient evidence for support another hypothesis ( $\mathrm{HO}$ ), suggesting that consumers knowledge has no influence to decision for paying shadaqah.

\section{CONCLUSION}

Consumers have a lot of considerations before deciding to take action to pay for something. It is not only happen in buying product or taking services, but also happen in

paying some obligation. According to previous researches, consumers knowledge has important role to influence consumers decision to pay for their obligation.

In this case, we did some observations through questionnaires, to know what factor that most influencing consumers by breaking down the consumers knowledge into three sub variable (attributes, benefits, and satisfactions) to pay shadaqah in baitul maal of unisba.

The results of this reserach by using multiple regression analyses, shows that satisfaction variable has the highest influence to decision to pay shadaqah at Baitul Maal of Unisba.

\section{REFERENCES}

Askari, H. \&Roshanak T. (2005). The Principle Foundations of An Islamic Economy.BancaNazionaledelLavora Quarterly Review, 58, 235.

Cristopher H.Lovelock dan Lauren K. Wright. (2002).Principles of Service Marketing And Management,Internasional Edition. New Jersey: Prentice Hall International Inc.

F. JamesEngel,Roger D. Blackwell, Paul W. Miniard. (I994). PerilakuKonsumen. Jakarta: BinarupaAksara.

Garcia, M.M. \& Annabi H. (2002). Customer Knowledge Management. Journal of the Operational Research Society, 53, 8.

Gebert H., Geib M., Kolbe,L. \& Brenner,W. (2003). Knowledge-enabled customer relationship management: Integrating customer relationship management and knowledge management concept. Journal of Knowledge Mangement, 7, 5.

Heikal, M., Muammar K., Falahuddin (20I4). The Intention to Pay Zakat Commercial: An Application of Revised Theory of Planned Behavior. Journal of Economics and Behavioral Studies, 6, 9. 
Huda, N., Nova R., Yosi M., Purnama P. (2012). The Analysis of Attitudes, Subjective Norms, and Behavioral Control on Muzakki's Intention to Pay Zakah. International Journal of Business and Social Science, 3, 22.

John C Mowen dan Michael Minor. (200I). Consumer Behavior .6th edition.New Jersey : Prentice-Hall,Inc.

Philip Kotlerdan Kevin Lane Keller. (2012). I4th edition Marketing Management. New Jersey: Prentice Hall International.,Inc.

Philip Kotlerdan Garry A. (200I). Principles of Marketing. New Jersey:Prentice Hall International, Inc.

Prue, B., Stern, L.D., Hurley P., Catto G., Young D., \& Pfautz J. (20I5). Application of Personality Theories for The Design and Development of Cross-cultural Decision-making Tools.6th International Conference on Applied Human Factors and Ergonomics (AHFE 2015) and the Affiliated Conferences, AHFE 2015.

Rowley, J. (2002). Eight questions for customer knowledge management in ebusiness Journal of Knowledge Management. 6, 5 .

Samad, A. \& Lowell M. G. (2010). Development of Zakah and Zakah Coverage in Monotheistic Faiths. International Journal of Social Economics, 37, 4.

Syafei, Z. (20I5). Public Trust of Zakat Management in the Office of Religious Affairs, Cipocok Jaya, Serang, Banten, Indonesia. Journal of Management and Sustainability, 5, 3.

Uotila, V. (201 I). Customer Knowledge Utilization In Retail Decision-Making. Aalto University School of Economics

Yeung, A.H.W., Lo,V.H.Y., Yeung,A.C.L., \& Cheng, T.C.E. (2008). Specific customer knowledge and operational performance in apparel manufacturing. Internatio-nal Journal of Production Economics, II4.

You Z., Si Y.W., Zhang D., Zeng X.X., Leung., S.C.H., \& Li. T. (20I4). A Decision-Making Framework for Precision Marketing. Expert Systems with Applications. 